\title{
The Potential of Using Forest Waste as a Raw Material in Particleboard Manufacturing
}

\begin{abstract}
Halil İbrahim Şahin *
Wood particles and a mixture of forest waste were investigated as raw material for the particleboard industry. Urea formaldehyde resin was used as the adhesive in the production of the particleboards. Some chemical $(\mathrm{pH}$, dilute alkali solubility, hot and cold water solubility), physical (density, moisture, thickness swelling, and water absorption), mechanical (modulus of rupture, modulus of elasticity, internal bond strength, and screw holding strength) properties, as well as the contact angle values of the resulting particleboards were determined. Due to its needle litter and cone content, the forest waste exhibited a lower $\mathrm{pH}$ value and a higher content of extractive material than wood. Increasing the addition of forest waste led to significant reductions in the physical and mechanical properties of the particleboards. The addition of forest waste reduced the internal bond strength the most (56.6\%), whereas the least reduction (15.7\%) was in the value of screw holding strength perpendicular to the surface. The values of all panels except panel type $\mathrm{F}$ exceeded the minimum modulus of elasticity (1600 N mm-2) required for furniture production according to the EN 312-P2 standard. Results of the analyses showed that forest waste $(10 \%$ and $20 \%)$ is a suitable renewable raw material source for panel production.
\end{abstract}

Keywords: Contact angle; Forest waste; Wood particles; Particleboard; Urea formaldehyde

Contact information: Department of Forest Industry Engineering, Faculty of Forestry, Duzce University, Duzce, Turkey; *Corresponding author: halilibrahimsahin@duzce.edu.tr;hisahin61@gmail.com

\section{INTRODUCTION}

The growing population, new usage areas, and technological developments are boosting particleboard consumption at a rapid pace. According to the Food and Agriculture Organization (FAO) 2018 statistical data, particleboard produced in Turkey amounts to $4,286,000 \mathrm{~m}^{3}$. With this production amount, Turkey ranks fifth in the world and is the fourth largest particleboard manufacturer in Europe. Turkey, with a medium and high density fiberboard (MDF/HDF) production of 4,747 million $\mathrm{m}^{3}$, ranks second after China in the world market. With this amount of production, it is the leader in the European market. Moreover, according to FAO data for 2016, Turkey, at 10 million $\mathrm{m}^{3}$, is the fifth largest consumer country of wood-based panels (FAO 2016). In terms of these data, new production resource alternatives to wood, as the main raw material of the panel industry (particleboard, MDF, HDF, OSB, etc.), will play an important role in reducing the pressure on Turkey's forests.

According to Turkey's General Directorate of Forestry data for 2015, the forest assets in Turkey amount to 22.3 million ha. The forest growing stock is 1.6 billion $\mathrm{m}^{3}$. Of this stock, $33 \%$ is broad-leaved forest (oak, beech, alder, chestnut, hornbeam, etc.), $48 \%$ is coniferous forest (Calabrian pine, black pine, Scots pine, fir, spruce, cedar, etc.), and the remaining $19 \%$ consists of mixed coniferous and broad-leaved forest. In terms of the 
distribution area of the tree species, oak shows the highest distribution with 5.9 million ha, followed by, according to the size of the area, Calabrian pine (5.6 million ha), black pine (2.7 million ha), beech (1.6 million ha), Scots pine, juniper, fir, cedar, spruce, stone pine, alder, chestnut, hornbeam, poplar, linden, ash, and eucalyptus (Orman Genel Müdürlüğü 2015). Almost all of these species have widespread uses in the forest products industry. Total biomass yield and leaf ratio vary according to the species and variety. Climate (moisture and solar radiation) and soil quality are the determining factors on biomass efficiency. The fresh leaf yield for some species in Turkey has been reported to be 27 ton/ha/year for oak tree leaves, although it changes depending on the diameter, and 4 to 11 ton/ha/year for Scots pine needles (Durkaya 1998; Ülker 2010).

The panel industry mainly uses different wood species as raw material. Raw material wood constitutes a significant part of total panel production costs. Alternative raw materials obtained from agricultural and forestry wastes are important natural resources for the panel industry because they are cheaper (Bektas et al. 2005; Şahin et al. 2017). In the production of particleboard and MDF, different lignocellulosic wastes can be mixed with wood or as a direct alternative raw material to wood (Guler et al. 2016; Gokdai et al. 2017; Kowaluk et al. 2020). Youngquist et al. (1994) found over 1000 research reports related to the use of non-wood plant fibers as building materials and for panel production. If alternative raw material sources to wood are to be used in the wood-based panel industry in the future, these materials must display properties equivalent to or better than those of wood.

While many developed countries in the world are evaluating agricultural waste fibers for production of composite panels, Turkey uses wood as a source of raw material in the production of composite boards (particleboard, fiberboard, plywood, etc.). The lignocellulosic forest wastes $(\mathrm{FW})$ to be added to the panel production will contribute to the use of raw material wood resources more rationally, economically, and in accordance with its purpose. In our country, approximately 40 to $45 \%$ of the wood and chips that are the raw material source of the panel industry can be obtained by importing them from other countries. In order to meet rapidly increasing production and consumption demands, the use of different raw materials is inevitable. For this purpose, many lignocellulosic raw materials have been used for the production of particleboard, including vine stems (Yeniocak et al. 2014), kenaf stem (Juliana et al. 2014), waste tea leaves (Batiancela et al. 2014), cotton stalk (Nazerian et al. 2016), flax chips (Sam-Brew and Smith 2017), corn stalk (Guler et al. 2016), sunflower stalk (Klimek et al. 2016), coir pith (Ahmed et al. 2016), poppy husk (Küçüktüvek et al. 2017), rice husk and bamboo stalk (De Melo et al. 2015), tobacco stalk (Acda and Cabangon 2013), rape straw (Dziurka et al. 2015), banana skins (Papadopoulos 2018), palm branches (Amirou et al. 2013), and reed stems (Kord et al. 2015).

Some studies have shown that if the forest and agricultural wastes are used in the particle board industry, the boards can be suitable based on EN standards. Pirayesh et al. (2015) investigated some physical (thickness swelling and water absorption) and mechanical (modulus of rupture, modulus of elasticity, internal bond strength) properties that were determined for particleboard produced with a mixture of maple leaves and wood chips. Panels were produced from five different wood-leaf mixtures (100/0, 90/10, 80/20, 70/30, and 60/40). The analyses showed that the physical and mechanical properties had been improved with up to $20 \%$ leaves, and all the panels produced met the EN standards required for furniture production. In addition, the use of sycamore leaf as a renewable biomaterial in particleboard production has been reported to reduce pressure on forests as 
well as contributing to the efficient utilization of the raw material.

Klimek et al. (2018) produced particleboards with a density of $0.60 \mathrm{~g} \mathrm{~cm}^{-3}$ and a thickness of $11 \mathrm{~mm}$, using MDI resin in different proportions (4\% and 6\%) with spruce chips and miscanthus stalks. A $30 \%$ decrease in modulus of rupture and modulus of elasticity values and a $60 \%$ reduction in internal bond strength were found in panels using the annual plant stalks compared to particleboards made from spruce chips. This was directly related to cell collapse occurring in the parenchyma cells of the annual plants.

Another study investigated the suitability of walnut/almond shell, a renewable agricultural waste, for the production of wood-based panels. Using urea formaldehyde adhesive, particleboards were produced with different amounts $(0 \%, 10 \%, 20 \%, 30 \%$, and $100 \%$ ) of walnut/almond shell. Some physical and mechanical properties and the formaldehyde emission values of the panels were determined. There were significant improvements in the water resistance of the boards with the addition of walnut/almond shell particles, while formaldehyde emissions were reduced to a large extent. The decreases in the mechanical properties were determined. In this study, it was stated that because of the low water absorption, thickness swelling, and formaldehyde emission rate, walnut/almond shells could be used as an alternative raw material or filler for the production of wood-based particleboards for indoor use (Pirayesh et al. 2013).

Developing value-added products from underutilized lignocellulosic biomass is an important opportunity for Turkey's forest resource management as well as for local economic development. From this point of view, the aim of this study was to use pine needle litter and broad-leaf that has no use, and pine cones, that are generally used as fuel or for their seeds, as alternative raw material in the particleboard industry.

\section{EXPERIMENTAL}

\section{Materials}

The pine needle litter, broad-leaf (oak and hornbeam, mixed) and cones (black pine and Scots pine, mixed) used in the production of the panels were obtained from the Kastamonu and Sinop regions in Turkey. The impurities (stones, soil, twigs, etc.) were removed. The cones were opened and the seeds removed. Afterwards, each sample was chipped separately in a Willey mill and placed in a bag. The forest wastes (FW) and wood particles (WP) are presented in Fig. 1a-c.

\section{Methods}

\section{Production of test panels}

The FW provided for the experimental study were mixed with WP for use in the core layer of the particleboards. Taking this situation into consideration, a two-stage sieving was carried out to render the FW suitable for particleboard production. Samples were first classified using $10.5 \times 10.5 \mathrm{~mm}$ mesh sieves in accordance with industrial factory production. Waste remaining on the sieve was removed. The particles passed through these sieves were then reclassified in 2.1 and $0.7 \mathrm{~mm}$ sieves and the wood, leaf and cone particles remaining on the sieve were classified separately for use in the core and surface layers of the particleboards, respectively. 


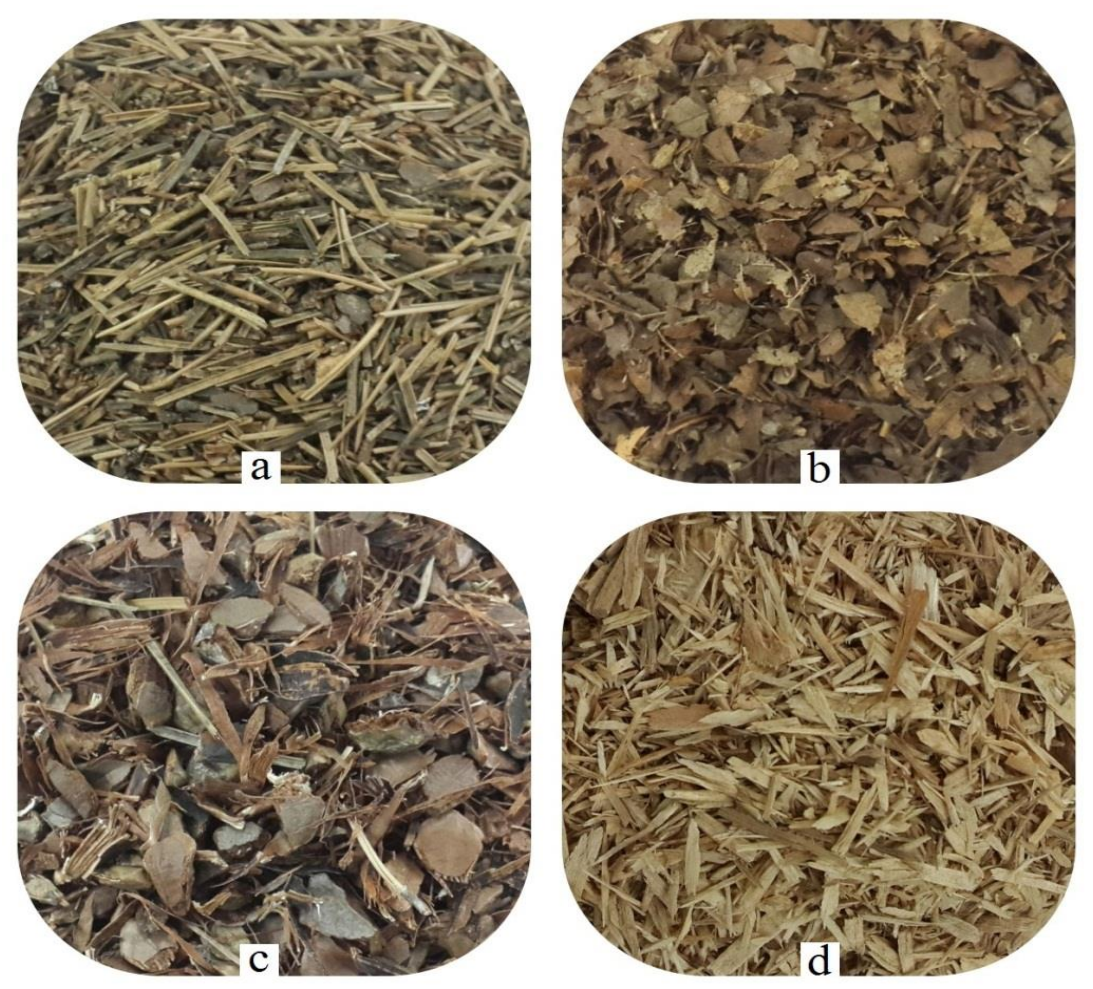

Fig. 1. The raw materials used in the production of particleboard: a) needle litter; b) broad-leaf; c) pine cones; d) WP

All WP used in the surface layers of the particleboards was supplied from a private particleboard factory (Kastamonu Entegre Inc.) in Turkey. Production of the core layer of the panels was carried out by mixing WP and FW (needle litter, broad-leaf, and pine cones) in designated proportions $(0 \%, 10 \%, 20 \%, 30 \%, 40 \%$, and $50 \%)$. The WP used in the core layers of the panels were supplied from the same factory in the size and moisture content suitable for the production of the panels. The WP content consisted of $60 \%$ pine and spruce wood and $15 \%$ oak wood, while the forest industry wastes made up $25 \%$ (Fig. 1d).

Particleboards with three layers were produced. The urea formaldehyde (UF) resin used in making the test panels was obtained from a factory producing particleboard in Izmit, Turkey. Technical characteristics of the UF resin are shown in Table 1.

Table 1. Technical Properties of Urea Formaldehyde (UF) Resin

\begin{tabular}{|c|c|}
\hline Adhesive Properties & UF \\
\hline Solid $(\%)$ & 51.9 \\
\hline Density $\left(\mathrm{g} \mathrm{cm}^{-3}\right)$ & 1.215 \\
\hline Formaldehyde/urea & 1.22 \\
\hline Viscosity $(\mathrm{cps})$ & $110-160$ \\
\hline $\mathrm{pH}$ & 8.52 \\
\hline Gel time (s) & 77 \\
\hline Water tolerance & $50 / 180$ \\
\hline Storage time (day) & 90 \\
\hline
\end{tabular}


Depending on the oven dry weight of the particles, the UF resin was used at $11 \%$ for the surface layers and $9 \%$ for the core layer. As a hardening agent, 20\% ammonium sulfate was added at a rate of $1 \%$ to the prepared resin solution. No water-repellent chemicals were used in the production of the particleboard. The experimental design used in the panel production is given in Table 2.

Table 2. Experimental Design for Particleboard Production

\begin{tabular}{|c|c|c|c|}
\hline \multirow{2}{*}{ Board Type } & Surface Layer & \multicolumn{2}{|c|}{ Core Layer } \\
\cline { 2 - 4 } & WP (\%) & ${ }^{*} F W(\%)$ & WP (\%) \\
\hline A & 40 & 0 & 60 \\
\hline B & 40 & 10 & 50 \\
\hline C & 40 & 20 & 40 \\
\hline D & 40 & 30 & 30 \\
\hline E & 40 & 40 & 20 \\
\hline F & 40 & 50 & 10 \\
\hline
\end{tabular}

* Forest waste (FW) consisted of pine cones, needle litter, and broad-leaf; all wastes were weighed in equal amounts during panel production and added to the core layer of particleboards.

Prior to gluing, the FW particles used in the production of the test panels were kept in a laboratory-type drying oven at $70{ }^{\circ} \mathrm{C}$ for 1 to 2 days until they achieved 1 to $3 \%$ moisture content. In the panel production, the amount of resin used for the particles mixture was calculated separately for the surface and core layers. The bonding process was carried out by weighing the amount of chips determined for each layer. Particleboard production parameters and pressing conditions are shown in Table 3.

Table 3. Particleboard Production Parameters

\begin{tabular}{|c|c|}
\hline Parameter & Value \\
\hline Press temperature $\left({ }^{\circ} \mathrm{C}\right)$ & 150 \\
\hline Peak pressure $\left(\mathrm{kg} \mathrm{cm}^{-2}\right)$ & 25 \\
\hline Pressing time $(\mathrm{min})$ & 10 \\
\hline Thickness $(\mathrm{mm})$ & 18 \\
\hline Dimensions $(\mathrm{mm})$ & $550 \times 580$ \\
\hline Surface layer (total board \%) & 40 \\
\hline Core layer (total board $\%)$ & 60 \\
\hline Target density of panel $\left(\mathrm{g} \mathrm{cm}^{-3}\right)$ & 0.65 \\
\hline Number of boards for each type & 2 \\
\hline
\end{tabular}

Stop bars were used to ensure that the test panels were of uniform 18-mm thickness. After aluminum foil was placed on the press plate to prevent sticking, the surface layer chips were homogeneously laid and the mat was hand-formed. The core layer and the second surface layer chips were then laid in place. After the laying process, the mat was pressed and compressed with a plate in the shape of the forming frame. Thus, the chips 
were consolidated by cold pressing at a certain rate before the hot pressing. The mats coming out of the cold press were pressed with an electrically heated single-layer hydraulic press having a pressing area of $550 \times 580 \mathrm{~mm}$. For physical and mechanical tests, two test panels were produced from each panel type to make 12 test panels in total (Fig. 2a).
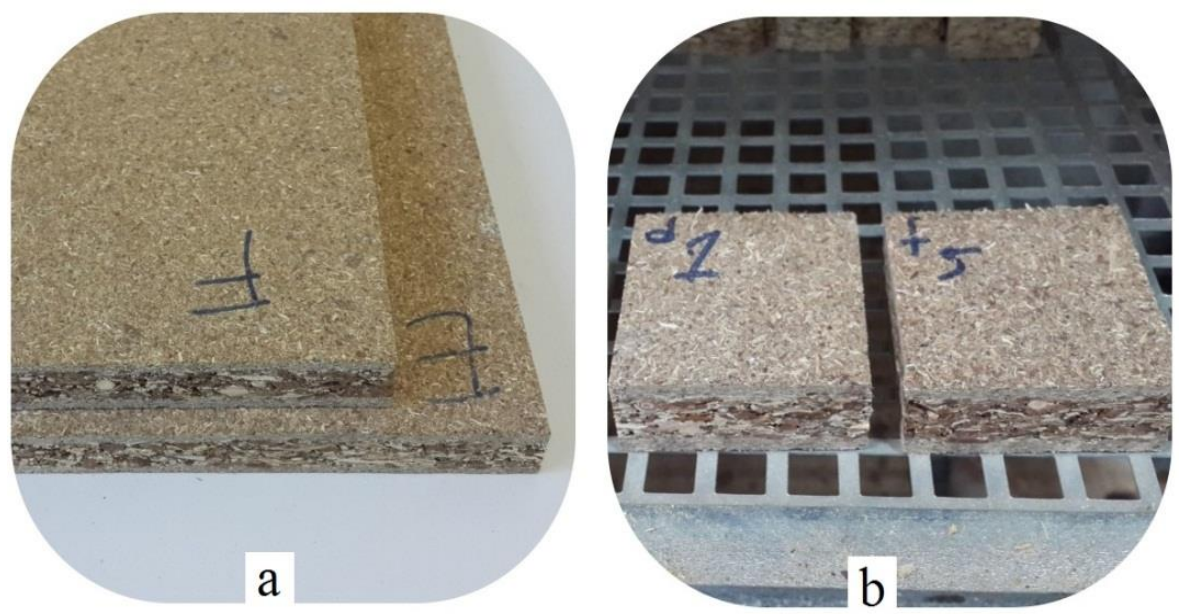

Fig. 2. Outside appearance of the experimental panels (a) and test samples (b)

\section{Specimen preparation and testing}

After the hot press, the panels were left to cool between the press plates as the glue continued to harden. In this way, the cooled panels were kept for three weeks in a climate controlled room at $20 \pm 2{ }^{\circ} \mathrm{C}$ and $65 \pm 5 \%$ relative humidity in accordance with the ISO 554 (1976) standard. Later, test samples were prepared from the produced panels in the dimensions specified by the standards.

WP and FW particles for solubility and $\mathrm{pH}$ analyses were evaluated and prepared according to TAPPI T $257 \mathrm{~cm}-12$ (2012). The $1 \% \mathrm{NaOH}$ solubility was determined using TAPPI T 212 om-12 (2012), hot and cold water solubility using TAPPI T $207 \mathrm{~cm}-08$ (2008), and pH analysis using TAPPI T 252 om-07 (2007) standard methods. Three replicates were made for each analysis.

Among the physical properties of the test panels, moisture content was determined according to EN 322 (1993), density according to EN 323 (1993), water absorption (WA), and thickness swelling (TS) for 2 and $24 \mathrm{~h}$ according to EN 317 (1993) standards. Test samples in dimensions of $50 \times 50 \times 18 \mathrm{~mm}$ were prepared to determine the physical properties (Fig. 2b). Five replicate test samples were used for moisture content measurements and 10 replicate samples were used for other properties.

Contact angle (CA) measurements were conducted using the Attention Theta Contact Angle Meter (Nanoscience, Phoenix, AZ, USA). After a $5 \mu \mathrm{L}$ droplet of purified water was dripped on the panel surface, the CA was determined at 1-s intervals for 25-s. Four test samples from each type of panel in dimensions of $50 \times 50 \times 8 \mathrm{~mm}$ were utilized for $\mathrm{CA}$ evaluation. The CA measurement was performed in three replicates per panel (Buyuksari et al. 2010a).

The mechanical properties of modulus of rupture (MOR) and modulus of elasticity (MOE) were determined according to EN 310 (1993). The three-point loading method was applied for these tests. Test samples were prepared in the dimensions of $400 \times 50 \times 18 \mathrm{~mm}$. Internal bond strength (IB) testing was carried out on test samples measuring $50 \times 50 \times 18$ 
mm according to EN 319 (1993). According to EN 320 (2011), test samples in dimensions of $75 \times 75 \times 18 \mathrm{~mm}$ were used for screw-holding strength (SHS) perpendicular to the surface. In determining all the mechanical properties of the produced particleboards, 10 replications were made for each group of panels. Test results were evaluated according to the limit values specified in the EN 312 (2010) standard. A universal test machine with a $20 \mathrm{KN}$ capacity load cell was used to determine the mechanical properties.

\section{Statistical analysis}

The data were analyzed using SPSS 19 statistical software. The confidence level was taken as 0.05 (95\%) for all comparisons. The presence of statistical differences between the test groups was determined by analysis of variance (ANOVA) for each experiment performed. If significant differences were found between the groups, the Duncan test was applied.

\section{RESULTS AND DISCUSSION}

\section{Chemical Properties}

The $\mathrm{pH}$ values, hot and cold water solubility, and $1 \% \mathrm{NaOH}$ solubility results of FW (cone, broad-leaf and needle litter) added to the particleboard production are shown in Table 4.

Table 4. Chemical Properties of FW and Softwood/Hardwood (Fengel and Wegener 1989)

\begin{tabular}{|c|c|c|c|c|c|}
\hline Properties & Softwood & Hardwood & Cone & $\begin{array}{c}\text { Broad } \\
\text { leaf }\end{array}$ & $\begin{array}{c}\text { Needle } \\
\text { litter }\end{array}$ \\
\hline $\mathrm{pH}$ & - & - & $4.15(0.20)$ & $4.75(0.26)$ & $3.28(0.11)$ \\
\hline $1 \% \mathrm{NaOH}$ solubility (\%) & $9-16$ & $14-20$ & $24.6(0.07)$ & $42.1(0.09)$ & $46.0(0.80)$ \\
\hline Hot water solubility (\%) & $3-6$ & $2-7$ & $8.42(0.08)$ & $9.75(0.02)$ & $12.9(0.10)$ \\
\hline Cold water solubility (\%) & $2-3$ & $4-6$ & $0.75(0.34)$ & $2.27(0.13)$ & $4.99(0.07)$ \\
\hline
\end{tabular}

Values in parentheses are standard deviation values.

The $\mathrm{pH}$ values of the FW ranged between 3.28 and 4.75. In the production of particleboard, it is recommended that the wood chips have a $\mathrm{pH}$ of 5 to 6 for good adhesion. Lower $\mathrm{pH}$ values cause the resin to harden prematurely and weaken the bond between the chips (Nemli et al. 2008). The hot water and $1 \% \mathrm{NaOH}$ solubility values of the FW were higher than those of soft/hard woods. The highest dilute alkali $(1 \% \mathrm{NaOH})$ solubility values were obtained in pine needle litter. The low $\mathrm{pH}$ values and high solubility values of $\mathrm{FW}$ are due to the fact that these wastes have a high rate of extractive substances and resin acids. In contrast, the cold water solubility values of FW were close to those of soft/hard woods (Table 4). 


\section{Physical Properties}

The averages, standard deviation values, and Duncan test results for the moisture content, density, WA, and TS of the particleboards produced with the addition of FW are shown in Table 5. The moisture content and density values of all particleboard groups were found to be compatible with the values specified in the EN 312 (2010) standard. For 2- and 24-h water immersion, panel type A showed the lowest WA (38.8\% and 47.4\%) and TS values (14.9\% and $21.0 \%)$ of all the particleboards. Guler et al. (2008) reported that the lowest WA and TS values for the 24-h water immersion time of particleboards produced using peanut hull and wood chips were found in the control group (100\% wood) panels. In the present study, no statistically significant difference was found involving $\mathrm{D}$ to $\mathrm{F}$ for WA, or B to $\mathrm{F}$ for TS in the 24-h immersion time.

However, the average WA and TS amounts of the A type particleboards made of $100 \%$ wood were found to be significantly different from all the other panel types ( $p$ $<0.05$ ). Depending on the increase in the immersion time (from 2 to $24 \mathrm{~h}$ ), a significant increase in WA and TS were detected (Table 5).

Table 5. Physical Properties of Particleboards Produced from WP and FW

\begin{tabular}{|c|c|c|c|c|c|c|}
\hline \multirow{2}{*}{$\begin{array}{l}\text { Board } \\
\text { type }\end{array}$} & \multirow{2}{*}{$\begin{array}{c}\text { Moisture } \\
(\%)\end{array}$} & \multirow{2}{*}{$\begin{array}{l}\text { Density } \\
\left(\mathrm{g} \mathrm{cm}^{-3}\right)\end{array}$} & \multicolumn{2}{|c|}{ WA (\%) } & \multicolumn{2}{|c|}{ TS (\%) } \\
\hline & & & $2 \mathrm{~h}$ & $24 \mathrm{~h}$ & $2 \mathrm{~h}$ & $24 \mathrm{~h}$ \\
\hline$A$ & $\begin{array}{c}8.46 \mathrm{ab} \\
(0.12)\end{array}$ & $\begin{array}{c}0.663 \mathrm{a} \\
(0.03)\end{array}$ & $\begin{array}{c}38.83 \mathrm{a} \\
(2.28)\end{array}$ & $\begin{array}{c}47.37 \mathrm{a} \\
(3.31)\end{array}$ & $\begin{array}{c}14.86 \mathrm{a} \\
(1.21)\end{array}$ & $\begin{array}{c}20.97 \mathrm{a} \\
(2.27)\end{array}$ \\
\hline B & $\begin{array}{l}8.30 \mathrm{a} \\
(0.11)\end{array}$ & $\begin{array}{c}0.656 \mathrm{a} \\
(0.05)\end{array}$ & $\begin{array}{c}43.09 \mathrm{~b} \\
(4.55)\end{array}$ & $\begin{array}{c}51.01 \mathrm{~b} \\
(3.65)\end{array}$ & $\begin{array}{c}15.84 \mathrm{ab} \\
(1.84)\end{array}$ & $\begin{array}{c}21.77 \mathrm{~b} \\
(2.69)\end{array}$ \\
\hline C & $\begin{array}{l}8.30 a \\
(0.13)\end{array}$ & $\begin{array}{c}0.659 \mathrm{a} \\
(0.04)\end{array}$ & $\begin{array}{c}42.94 \mathrm{~b} \\
(2.00)\end{array}$ & $\begin{array}{c}51.90 \mathrm{bc} \\
(2.03)\end{array}$ & $\begin{array}{c}16.12 \mathrm{ab} \\
1.40\end{array}$ & $\begin{array}{c}24.15 b \\
(1.81)\end{array}$ \\
\hline $\mathrm{D}$ & $\begin{array}{l}8.41 \mathrm{a} \\
(0.10)\end{array}$ & $\begin{array}{c}0.658 \mathrm{a} \\
(0.05)\end{array}$ & $\begin{array}{c}43.90 \mathrm{~b} \\
(4.41)\end{array}$ & $\begin{array}{c}53.48 \mathrm{~cd} \\
(5.33)\end{array}$ & $\begin{array}{c}16.76 \mathrm{bc} \\
(1.23)\end{array}$ & $\begin{array}{c}25.00 \mathrm{~b} \\
(2.79)\end{array}$ \\
\hline$E$ & $\begin{array}{c}8.45 \mathrm{ab} \\
(0.17)\end{array}$ & $\begin{array}{c}0.661 \mathrm{a} \\
(0.03)\end{array}$ & $\begin{array}{c}44.68 \mathrm{~b} \\
(4.42)\end{array}$ & $\begin{array}{c}54.00 \mathrm{~d} \\
(4.55)\end{array}$ & $\begin{array}{c}17.89 \mathrm{c} \\
(1.94)\end{array}$ & $\begin{array}{c}25.77 \mathrm{~b} \\
(2.28)\end{array}$ \\
\hline$F$ & $\begin{array}{l}8.60 \mathrm{~b} \\
(0.09)\end{array}$ & $\begin{array}{c}0.658 \mathrm{a} \\
(0.05)\end{array}$ & $\begin{array}{c}46.66 \mathrm{c} \\
(2.64)\end{array}$ & $\begin{array}{c}54.94 \mathrm{~d} \\
(3.20)\end{array}$ & $\begin{array}{c}16.20 \mathrm{ab} \\
(1.48)\end{array}$ & $\begin{array}{c}25.65 \mathrm{~b} \\
(1.97)\end{array}$ \\
\hline $\mathrm{p}$ - value & 0.006 & 0.998 & 0.000 & 0.000 & 0.003 & 0.000 \\
\hline EN 312-P3 & $5-13 \%$ & $\pm 10 \%{ }^{A}$ & - & - & - & 14 \\
\hline EN 312-P4 & $5-13 \%$ & $\pm 10 \%$ & - & - & - & 15 \\
\hline
\end{tabular}

Values in parentheses are standard deviation values.

There is no statistical difference between the values indicated by the same letters in the column ( $p$ $>0.05$ ).

A: They are $\pm 10 \%$ acceptable values relative to the target density $\left(0.65 \mathrm{~g} \mathrm{~cm}^{-3}\right.$ in this study).

p-value: Significance level.

P3: Non-load-bearing boards for use in humid conditions.

P4: Load-bearing boards for use in dry conditions.

The effects of the addition of FW used in the production of the particleboards on their WA and TS values are shown in Fig. 3. The WA and the TS values increased depending on the increase in the contribution rate of the FW used in particleboard production. The percentage of variation in the TS values was higher than that of the WA in all other panels except the B type particleboards (Fig. 3). Similar results were reported 
by Guler et al. (2008). For 24-h water immersion time, with increasing FW usage, the average WA and TS values of the panels containing FW particles increased from $3.83 \%$ to $22.3 \%$ and $7.69 \%$ to $16.0 \%$, respectively, compared to values of the panels made from $100 \%$ WP (Fig. 3).

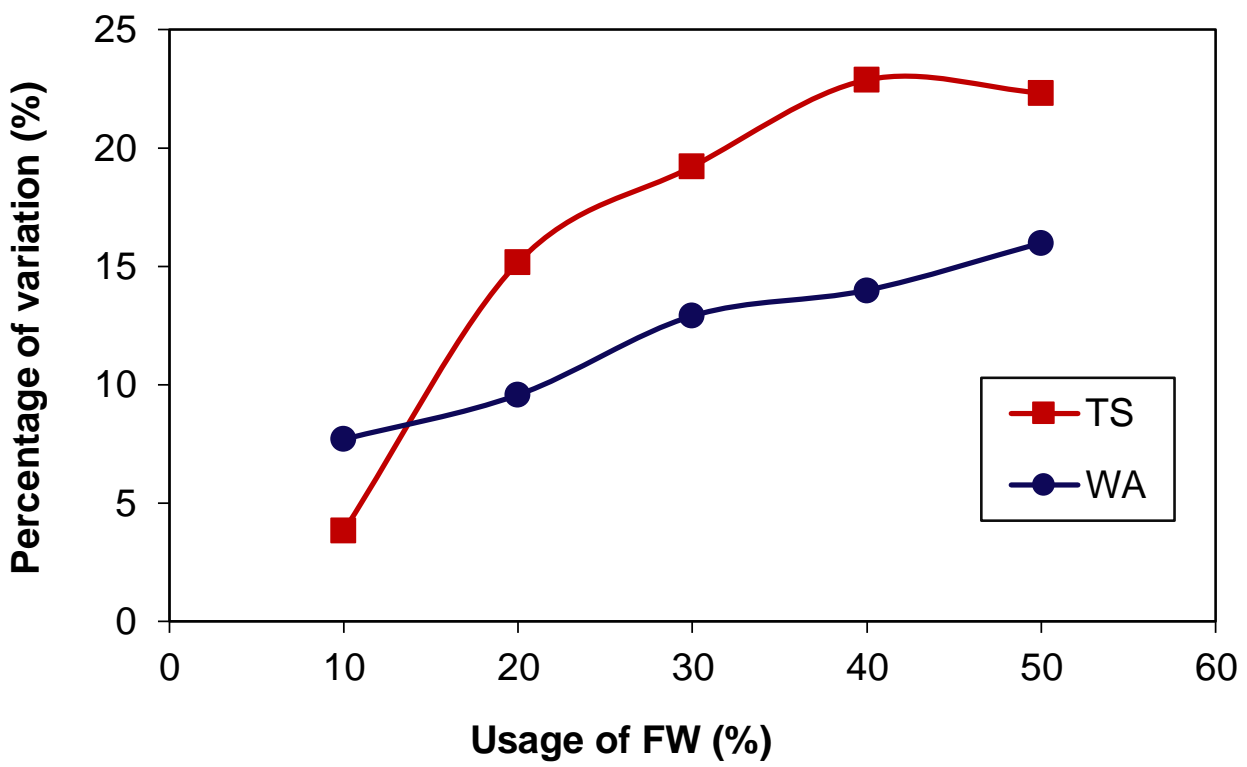

Fig. 3. Percent variation in physical properties of panels containing $\mathrm{FW}$ compared to panels made from $100 \%$ WP (for 24-h water immersion)

After 24-h of water immersion, the maximum TS values are specified as $14 \%$ for non-load-bearing boards for use in humid conditions and as $15 \%$ for load-bearing boards for use in dry conditions. It was observed that the TS values ranged between $21.0 \%$ and $25.8 \%$ for the 24-h water immersion of the particleboards produced from wood and additions of FW. None of the produced panels met the maximum requirements set by the standards. This was thought to be due to the absence of any water repellent (hydrophobic) chemicals or oils in the production of the particleboards. Pirayesh et al. (2015) stated that particleboards with wood and sycamore leaf added could not meet the requirements set by EN 312-3. Similar results have been reported in the literature when particleboards with different agricultural and forestry wastes used as raw materials were immersed in water for 24 h (Bektas et al. 2005; Borysiuk et al. 2019; Kowaluk et al. 2020). Many factors affect the TS values of particleboards. These factors depend on the type, quantity, and distribution of the resin used, the chemical structure of the chips, the pressing conditions (temperature, time and duration), the compatibility of the resin and chips, and the moisture of the chips and their density and dimensions (Nemli and Aydin 2007; Guler et al. 2008; Pirayesh et al. 2015; Borysiuk et al. 2019). The water repellant properties of panels can be improved by application of water-repellent chemicals such as paraffin, acetylation of the chips, using phenolic resins, coating the surfaces of the boards, and heat treatment (Nemli et al. 2005; Ayrilmis et al. 2009; Buyuksari et al. 2010b).

Figure 4 shows time-dependent variation in CA values of the particleboards produced from wood and forestry wastes. It was observed that the CA values of all panels decreased with the increase in time duration. The highest $\mathrm{CA}$ values were obtained for panels containing 50\% FW (panel type F), while the lowest CA values were observed in 
particleboards made from 100\% WP (panel type A). The average CA values of the panels also increased depending on the increase in the FW content. These increases were seen to range between 33 and 141\% compared to type A particleboards. Buyuksari et al. (2010a) found significant increases in the CA values of particleboards with the increased content of stone pine cones. The wettability of chips were affected by various factors such as density, chemical content of the raw material, permeability, surface roughness, measuring method, temperature, reference fluid, fluid viscosity, and surface tension (Oliveira et al. 2010; Shen et al. 2011; Baharoğlu et al. 2012; Zhang and Hu 2014; Xu et al. 2016). Pine needle litter and pine cones contain higher amounts of extractive substances than wood (Nemli et al. 2008; Buyuksari et al. 2010a). Moreover, broad leaves have an oily epidermal surface layer. This layer prevents good adhesion of leaf particles when using water-based adhesives (Campanella et al. 2013). For this reason, the wettability values of the particleboards produced from FW (needle litter, broad-leaf and pine cone) were lower than those of the panels produced from $100 \%$ wood. As a result of poor adhesion, TS values increased with increasing FW content in the particleboard production (Table 5 and Fig. 3).

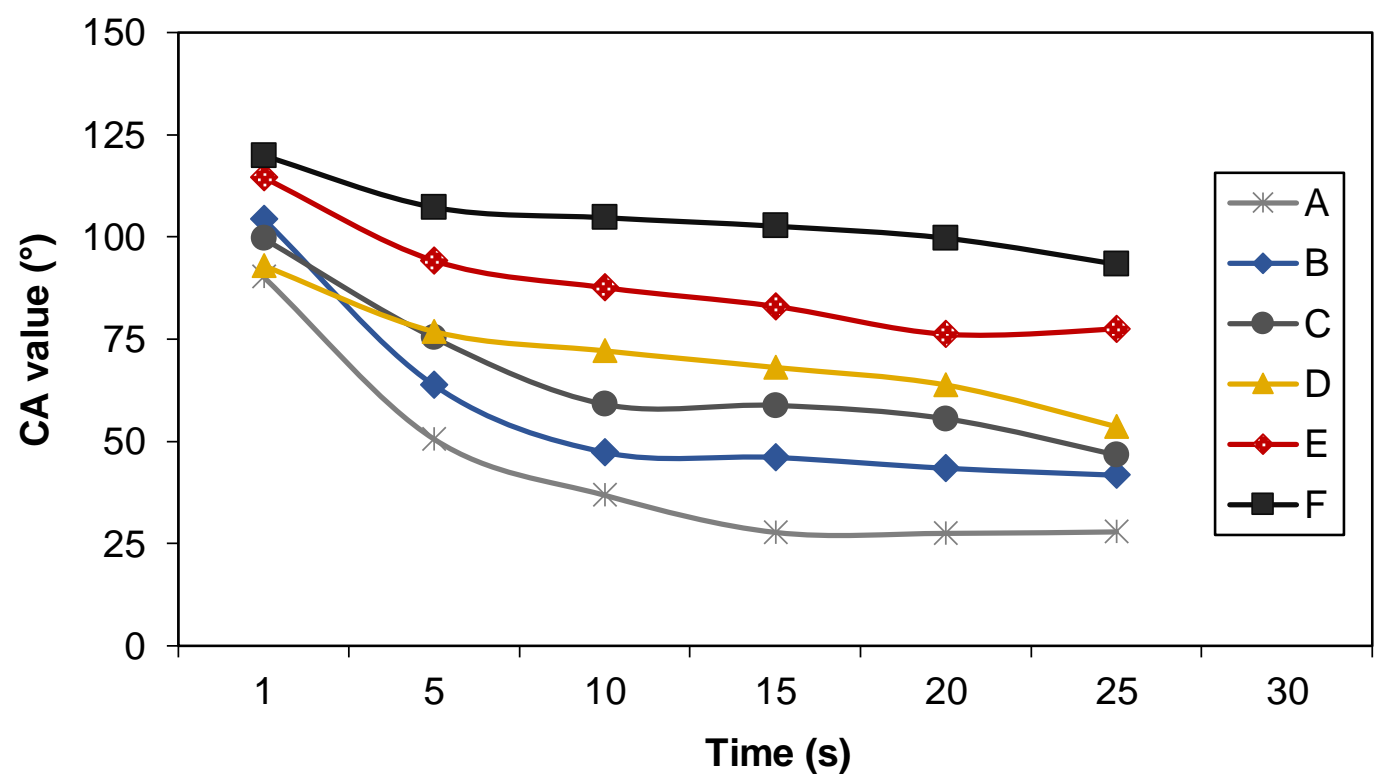

Fig. 4. Percent variation in physical properties of panels containing FW compared to panels made from $100 \%$ WP (for 24-h water immersion)

\section{Mechanical Properties}

The results of ANOVA and Duncan's mean separation tests for MOR, MOE, IB, and SHS values for particleboards made of wood and FW are shown in Table 6. The highest MOR, MOE, IB, and SHS values were obtained for the particleboards made of $100 \%$ wood. However, the lowest mechanical strength values were observed in particleboards (type F) having 50\% FW in the mixture. Guler et al. (2008) reported similar results for particleboards produced from peanut hull. Statistically significant differences were found between some groups of the produced particleboards for MOR, MOE, and IB strength values.

Although there was no statistically significant difference between the A and B type panels for MOR and MOE, these panel groups were found to be different from all the other panels (Table 6). According to the EN 312 (2010) standard, the MOR and IB strength 
requirements for general purpose (P1) boards and for interior fitments (including furniture) (P2) for use in dry conditions are 10 and $11 \mathrm{~N} / \mathrm{mm}^{2}$ and 0.24 and $0.35 \mathrm{~N} / \mathrm{mm}^{2}$, respectively. The MOR, MOE, and IB strength values of the A-C type panels were found to meet the minimum requirements for general purpose boards for use in dry conditions (Table 6). All except panel type $\mathrm{F}$ met the minimum MOE $\left(1600 \mathrm{~N} / \mathrm{mm}^{2}\right)$ required for furniture production according to EN 312 (2010) standard. However, none of the boards were able to meet the IB values required for P2 application areas. Nemli et al. (2008) stated that except for panels made of $100 \%$ wood, no other panels met the minimum MOR, MOE, and IB values required for furniture production.

Table 6. Mechanical Properties Test Results of ANOVA and Duncan's Mean Separation Tests of Particleboards Manufactured from FW and WP

\begin{tabular}{|c|c|c|c|c|}
\hline $\begin{array}{c}\text { Board } \\
\text { type }\end{array}$ & $\begin{array}{c}\text { MOR } \\
\left(\mathrm{N} \mathrm{mm}^{-2}\right)\end{array}$ & $\begin{array}{c}\mathrm{MOE} \\
\left(\mathrm{N} \mathrm{mm}^{-2}\right)\end{array}$ & $\begin{array}{c}\text { IB } \\
\left(\mathrm{N} \mathrm{mm}^{-2}\right)\end{array}$ & $\begin{array}{c}\text { SHS } \\
(\mathrm{N})\end{array}$ \\
\hline $\mathrm{A}$ & $12.3(0.41) \mathrm{a}$ & $2202(109) \mathrm{a}$ & $0.29(0.01) \mathrm{a}$ & $700(59) \mathrm{a}$ \\
\hline $\mathrm{B}$ & $11.9(0.59) \mathrm{a}$ & $2171(120) \mathrm{a}$ & $0.27(0.05) \mathrm{a}$ & $691(62) \mathrm{a}$ \\
\hline $\mathrm{C}$ & $10.2(0.81) \mathrm{b}$ & $2008(74) \mathrm{b}$ & $0.25(0.02) \mathrm{a}$ & $653(65) \mathrm{ab}$ \\
\hline $\mathrm{D}$ & $9.1(0.78) \mathrm{c}$ & $1676(83) \mathrm{c}$ & $0.18(0.02) \mathrm{b}$ & $598(49) \mathrm{bc}$ \\
\hline $\mathrm{E}$ & $7.9(0.90) \mathrm{d}$ & $1613(108) \mathrm{c}$ & $0.13(0.03) \mathrm{c}$ & $622(67) \mathrm{bc}$ \\
\hline $\mathrm{F}$ & $6.7(0.40) \mathrm{e}$ & $1466(93) \mathrm{d}$ & $0.13(0.01) \mathrm{c}$ & $590(45) \mathrm{c}$ \\
\hline $\mathrm{p}-$ value & 0.000 & 0.000 & 0.000 & 0.000 \\
\hline EN 312-P1 & 10 & - & 0.24 & - \\
\hline EN 312-P2 & 11 & 1600 & 0.35 & - \\
\hline
\end{tabular}

Mean values for mechanical properties are the average of 10 samples.

Values in parentheses are standard deviation values.

There is no statistical difference between the values indicated by the same letters in the column ( $p$ $>0.05$ ).

p-value: Significant level.

P1: General purpose boards for use in dry conditions.

P2: Boards for interior fitments (including furniture) for use in dry conditions.

The values of SHS perpendicular to the surface were determined to vary between 590 and 700 N. Similar to other mechanical properties, the values of SHS perpendicular to the surface decreased with the increase in FW in the mixture. Guler et al. (2006) found that the values for SHS perpendicular to the panel surface ranged from 595 to $944 \mathrm{~N}$ for particleboards produced from sunflower stalk. Although the highest values for SHS perpendicular to the surface were obtained for the panels made of $100 \%$ wood, the lowest values were seen for the panels with $30 \% \mathrm{FW}$ in the mixture. The effect of the addition of FW used in production on the mechanical properties of particleboards is shown in Fig. 5.

All mechanical properties of the panels decreased depending on the increase in FW in the mixture. Similar results were reported for agricultural, forest, and annual-plant wastes by authors in previous studies (Bektas et al. 2005; Guler et al. 2008; Nemli et al. 2008; Ayrilmis et al. 2009; Buyuksari et al. 2010b). The addition of FW reduced the IB the most (56.6\%), while the least reduction (15.7\%) was in the value of SHS perpendicular to the surface (Fig. 5). There are several reasons for these reductions in mechanical 
properties. The most important of these is that $\mathrm{FW}$ have lower $\mathrm{pH}$ values and higher extractive contents compared to wood (Nemli and Aydın 2007). Low pH causes pre-curing of the resin, thus weakening the bond between the chips before hot pressing. The high extractive content has a similar effect and reduces the IB strength between the chips (Nemli et al. 2008; Ayrilmis et al. 2009). In addition, the oily surface layer on the broad-leaf particles reduces compatibility between water-based adhesives and the wood particles (Campanella et al. 2013).

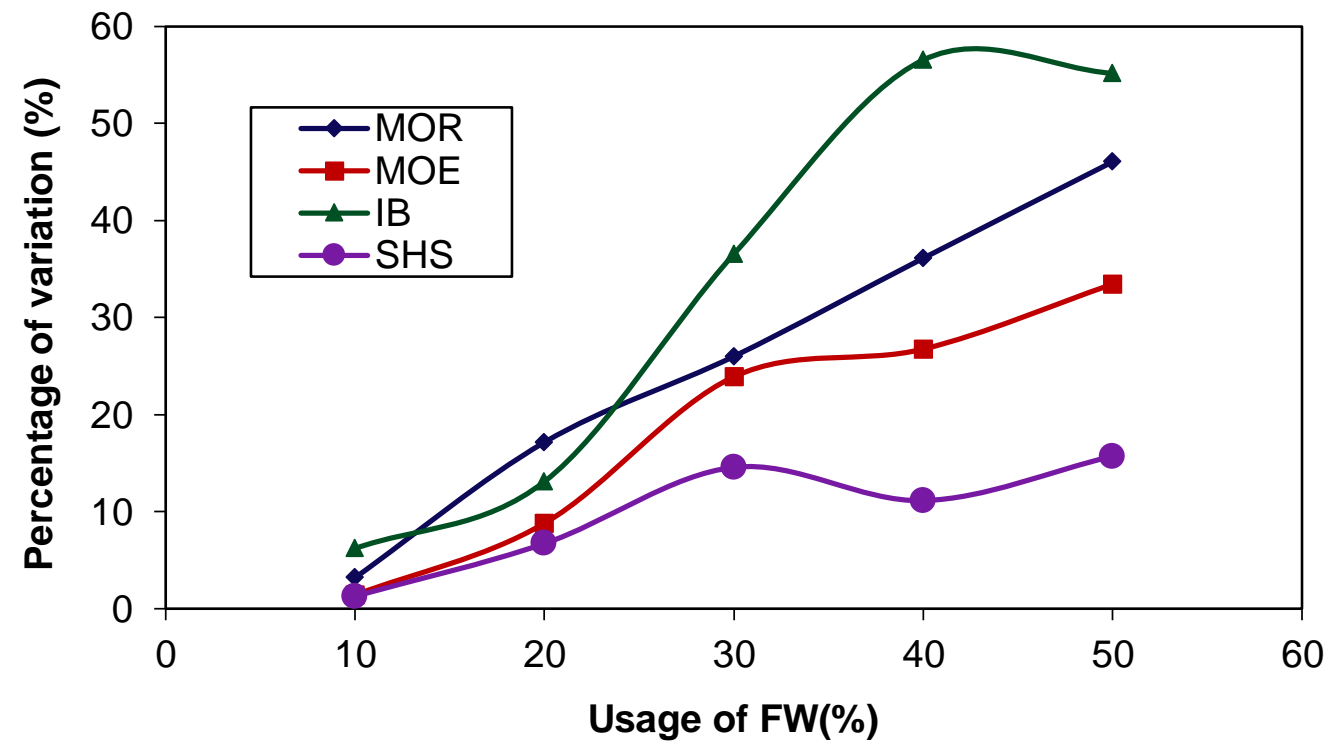

Fig. 5. Percent of variation in mechanical properties of panels containing FW compared to panels made from $100 \%$ WP

\section{CONCLUSIONS}

1. The analyses showed that it is possible to produce particleboard using a mixture of forest wastes (FW) (10\% and $20 \%$ panel types $\mathrm{A}$ and $\mathrm{B}$, respectively) and wood particles (WP) bonded with urea formaldehyde resin.

2. The FW exhibited lower $\mathrm{pH}$ values and a higher amount of extractive material compared to WP.

3. Although the lowest contact angle (CA) values were found in the panels produced with $100 \% \mathrm{WP}$, the highest values were found in the particleboards containing $50 \% \mathrm{FW}$ in the core layer.

4. Increase in FW percentage in the mixture resulted in a lower physical and mechanical properties for particleboards produced using $\mathrm{FW}$ and wood chip mixtures. The particleboards produced utilizing FW give higher water absorption (WA) and thickness swelling (TS) values compared to panels made from WP. However, the WA and TS values of the panels could be improved by hydrophobic additives.

5. Based on EN standards, all particleboards met the minimum requirements the modulus of rupture (MOR) for furniture manufacturing except for the panels containing $50 \%$ FW (group F). 


\section{ACKNOWLEDGMENTS}

The author thanks Peachy Nuriye Eleanor for contributions in developing and editing the English text of the manuscript. I would like to thank Volkan Çavdar for the supply of WP and UF glue. Fahri Akkaya is acknowledged for his help and advice on testing materials. Also, I thank him for his support in collecting and milling of FW.

\section{REFERENCES CITED}

Acda, M. N., and Cabangon, R. J. (2013). "Termite resistance and physico-mechanical properties of particleboard using waste tobacco stalk and wood particles," International Biodeterioration \& Biodegradation 85, 354-358. DOI: 10.1016/j.ibiod.2013.08.019

Ahmed, E., Das, A. K, Hannan, M. O, and Shams, M. I. (2016). "Particleboard from coir pith," Bangladesh Journal of Scientific and Industrial Research 51(3), 239-245. DOI: 10.3329/bjsir.v51i3.29436

Amirou, S., Zerizer, A., Pizzi, A., Haddadou, I., and Zhou, X. (2013). "Particleboards production from date palm biomass," European Journal of Wood and Wood Products 71(6), 717-723. DOI: 10.1007/s00107-013-0730-3

Ayrilmis, N., Buyuksari, U., Avci, E., and Koc, E. (2009). "Utilization of pine (Pinus pinea L.) cone in manufacture of wood-based composite," Forest Ecology and Management 259(1), 65-70. DOI: 10.1016/j.foreco.2009.09.043

Baharoğlu, M., Nemli, G., Sari, B., Bardak, S., and Ayrilmiş, N. (2012). "The influence of moisture content of raw material on the physical and mechanical properties, surface roughness, wettability, and formaldehyde emission of particleboard composite," Composites Part B: Engineering 43(5), 2448-2451. DOI: 10.1016/j.compositesb.2011.10.020

Batiancela, M. A., Acda, M. N., and Cabangon, R. J. (2014). "Particleboard from waste tea leaves and wood particles," Journal of Composite Materials 48(8), 911-916. DOI: $10.1177 / 0021998313480196$

Bektas, I., Guler, C., Kalaycioglu, H., Mengeloglu, F., and Nacar, M. (2005). “The manufacture of particleboards using sunflower stalks (Helianthus annuus L.) and poplar wood (Populus alba L.)," Journal of Composite Materials 39(5), 467-473. DOI: $10.1177 / 0021998305047098$

Borysiuk, P., Jenczyk-Tolloczko, I., Auriga, R., and Kordzikowski, M. (2019). "Sugar beet pulp as raw material for particleboard production," Industrial Crops and Products 141, 111829. DOI: 10.1016/j.indcrop.2019.111829

Buyuksari, U., Avci, E., Ayrilmis, N., and Akkilic, H. (2010a). "Effect of pine cone ratio on the wettability and surface roughness of particleboard," BioResources 5(3), 18241833. DOI: 10.15376/biores.5.3.1824-1833

Buyuksari, U., Ayrilmis, N., Avci, E., and Koc, E. (2010b). "Evaluation of the physical, mechanical properties and formaldehyde emission of particleboard manufactured from waste stone pine (Pinus pinea L.) cones," Bioresource Technology 101(1), 255259. DOI: 10.1016/j.biortech.2009.08.038

Campanella, A., Wool, R. P., Bah, M., Fita, S., and Abuobaid, A. (2013). "Composites from northern red oak (Quercus robur) leaves and plant oil-based resins," Journal of Applied Polymer Science 127(1), 18-26. DOI: 10.1002/app.36663 
De Melo, R., Stangerlin, D., Santana, R. R. C., and Pedrosa, T. D. (2015). "Decay and termite resistance of particleboard manufactured from wood, bamboo and rice husk," Maderas: Ciencia y Tecnología 17(1), 55-62. DOI: 10.4067/S0718221X2015005000006

Durkaya, B. (1998). Construction of Biomass Tables of Quercus in Zonguldak Forest Region Administration, M.Sc. Thesis, Zonguldak Karaelmas University, Zonguldak, Turkey.

Dziurka, D., Mirski, R., Dukarska, D., and Derkowski, A. (2015). "Possibility of using the expanded polystyrene and rape straw to the manufacture of lightweight particleboards," Maderas. Ciencia y Tecnología 17(3), 647-656. DOI: 10.4067/S0718-221X2015005000057.

EN 310 (1993). "Wood-based panels: Determination of modulus of elasticity in bending and of bending strength," European Committee for Standardization, Brussel, Belgium.

EN 312 (2010). "Particleboards. Specifications, European Committee for Standardization," Brussel, Belgium.

EN 317 (1993). "Particleboards and fibreboards: Determination of swelling in thickness after immersion in water," European Committee for Standardization, Brussel, Belgium.

EN 319 (1993). "Particleboards and fiberboards: Determination of tensile strength perpendicular to plane of the board," European Committee for Standardization, Brussels, Belgium.

EN 320 (2011). "Particleboards and fibreboards: Determination of resistance to axial withdrawal of screws," European Committee for Standardization, Brussels, Belgium.

EN 322 (1993). "Wood-based panels: Determination of moisture content," European Committee for Standardization, Brussel, Belgium.

EN 323 (1993). "Wood-based Panels: Determination of Density," European Committee for Standardization, Brussel, Belgium.

Fengel, D., and Wegener, G. (1989). Wood: Chemistry, Ultrastructure, Reactions, Walter de Gruyter \& Co, Berlin, Germany.

FAO (2016). "Global forest products facts and figures 2016," Food and Agriculture Organization (FAO) of the United Nation (UN), Rome, Italy, (http://www.fao.org/3/I7034EN/i7034en.pdf), Accessed 11 Mar 2019.

FAO (2018). Forestry production and trade databased, (http://www.fao.org/faostat/en/\#data/FO), Accessed 20 June 2020.

Gokdai, D., Borazan, A. A., and Acikbas, G. (2017). "Effect of marble: Pine cone waste ratios on mechanical properties of polyester matrix composites," Waste and Biomass Valorization 8(5), 1855-1862. DOI: 10.1007/s12649-017-9856-6

Guler, C., Copur, Y., and Tascioglu, C. (2008). "The manufacture of particleboards using mixture of peanut hull (Arachis hypoqaea L.) and European Black pine (Pinus nigra Arnold) wood chips," Bioresource Technology 99(8), 2893-2897. DOI: 10.1016/j.biortech.2007.06.013

Guler, C., Bektas, I., and Kalaycioglu, H. (2006). "The experimental particleboard manufacture from sunflower stalks (Helianthus annuus L.) and Calabrian pine (Pinus brutia Ten.)," Forest Products Journal 56(4), 56-60. DOI:

Guler, C., Sahin, H. I., and Yeniay, S. (2016). "The potential for using corn stalks as a raw material for production particleboard with industrial wood chips," Wood Research 61(2), 299-306. 
ISO 554 (1976). "Standard atmosphere for conditioning and/or testing-Specifications," International Organization for Standardization, Switzerland.

Juliana, A. H., Paridah, M. T., Rahim, S., Nor Azowa, I., and Anwar, U. M. K. (2014). "Effect of adhesion and properties of kenaf (Hibiscus cannabinus L.) stem in particleboard performance" Journal of Adhesion Science and Technology 28(6), 546560. DOI: 10.1080/01694243.2013.848622

Klimek, P., Meinlschimidt, P., Wimmer, R., Plinke, B., and Schirp, A. (2016). "Using sunflower (Helianthus annuus L.), topinambour (Helianthus tuberosus L.) and cupplant (Silphium perfoliatum L.) stalks as alternative raw materials for particleboards," Industrial Crops and Products 92, 157-164. DOI: 10.1016/j.indcrop.2016.08.004

Klimek, P., Wimmer, R., Meinlschmidt, P., and Kúdela, J. (2018). "Utilizing miscanthus stalks as raw material for particleboards," Industrial Crops and Products 111, 270276. DOI: 10.1016/j.indcrop.2017.10.032

Kord, B., Roohani, M., and Kord, B. (2015). "Characterisation and utilization of reed stems as a lignocellulosic residue for particleboard production," Maderas: Ciencia y Tecnología 17(3), 517-524. DOI: 10.4067/S0718-221X2015005000046

Kowaluk, G., Szymanowski, K., Kozlowski, P., Kukula, W., Sala, C., Robles, E., and Czarniak, P. (2020). "Functional assessment of particleboards made of apple and plum orchard pruning," Waste and Biomass Valorization 11, 2877-2886. DOI: 10.1007/s12649-018-00568-8

Küçüktüvek, M., Kasal, A., Kuşkun, T., and Erdil, Y. (2017). "Utilizing poppy huskbased particleboards as an alternative material in case furniture construction," BioResources 12(1), 839-852. DOI: 10.15376/biores.12.1.839-852

Nazerian, M., Beyki, Z., Gargarii, R. M., and Kool, F. (2016). "The effect of some technological production variables on mechanical and physical properties of particleboard manufactured from cotton stalks," Maderas: Ciencia y Tecnología 18(1), 167-178. DOI: 10.4067/S0718-221X2016005000017

Nemli, G., Yildiz, S., and Gezer, E. D. (2008). "The potential for using the needle litter of Scotch pine (Pinus sylvestris L.) as a raw material for particleboard manufacturing," Bioresource Technology 99(14), 6054-6058. DOI: 10.1016/j.biortech.2007.12.044

Nemli, G., and Aydin, A. (2007). "Evaluation of the physical and mechanical properties of particleboard made from the needle litter of Pinus Pinaster Ait.," Industrial Crops and Products 26(3), 252-258. DOI: 10.1016/j.indcrop.2007.03.016

Nemli, G., Ors, Y., and Kalaycioglu, H. (2005). "The choosing of suitable decorative surface coating material types for interior end use applications of particleboard," Construction and Building Materials 19(4), 307-312. DOI:

10.1016/j.conbuildmat.2004.07.015

Oliveira, R. M. D., Brisolari, A., Sales, A., and Gonçalves, D. (2010). Wettability, shrinkage and color changes of Araucaria angustifolia after heating treatment," Materials Research 13(3), 351-354. DOI: 10.1590/S1516-14392010000300012

Orman Genel Müdürlüğü (OGM) (2015). “Türkiye orman varlığı," Orman İdaresi ve Planlama Dairesi Başkanlığı Yayınları, Ankara, Türkiye (in Turkish).

Papadopoulos, A. N. (2018). "Banana chips (Musa acuminate) as an alternative lignocellulosic raw material for particleboard manufacture," Maderas: Ciencia y Tecnología 20(3), 395-402. DOI: 10.4067/S0718-221X2018005031001

Pirayesh, H., Moradpour, P., and Sepahvand, S. (2015). "Particleboard from wood particles and sycamore leaves: Physico-mechanical properties," Engineering in Agriculture, Environment and Food 8(1), 38-43. DOI: 10.1016/j.eaef.2014.07.003 
Pirayesh, H., Khanjanzadeh, H., and Salari, A. (2013). "Effect of using walnut/almond shells on the physical, mechanical properties and formaldehyde emission of particleboard," Composites Part B: Engineering 45(1), 858-863. DOI: 10.1016/j.compositesb.2012.05.008

Sam-Brew, S., and Smith, G. D. (2017). "Flax shive and hemp hurd residues as alternative raw material for particleboard production," BioResources 12(3), 57155735. DOI: 10.15376/biores.12.3.5715-5735

Shen, J. H., Liu, Z. M., Li, J., and Niu, J. (2011). "Wettability changes of wheat straw treated with chemicals and enzymes," Journal of Forestry Research 22(1), 107-110. DOI: $10.1007 / \mathrm{s} 11676-011-0134-3$

Şahin, H. İ., Yalçin, M., and Yaglica, N. (2017). "Orta tabakası kompost atığı ilaveli yonga levhaların vida tutma gücü ve 1sı iletkenlik değerlerinin belirlenmesi," Artvin Çoruh Üniversitesi Orman Fakültesi Dergisi 18(2), 121-129 (in Turkish). DOI: 10.17474/artvinofd.320521

TAPPI T 252 om-07 (2007). "pH and electrical conductivity of hot water extracts of pulp, paper, and paperboard," TAPPI Press, Atlanta, GA.

TAPPI T 207 cm-08 (2008). "Water solubility of wood and pulp," TAPPI Press, Atlanta, GA.

TAPPI T 212 om-12 (2012). "One percent sodium hydroxide solubility of wood and pulp," TAPPI Press, Atlanta, GA.

TAPPI T 257 cm-12 (2012). "Sampling and preparing wood for analysis," TAPPI Press, Atlanta, GA.

Ülker, C. (2010). Construction of Biomass Tables of Scotch Pine in Amasya Forest Regional Headquarter (A Case Study of Kunduz Planning Unit). M.Sc. Thesis, Karadeniz Technical University, Trabzon, Turkey.

Xu, N., Liu, W., Hou, Q., Wang, P., and Yao, Z. (2016). "Effect of autohydrolysis on the wettability, absorbility and further alkali impregnation of poplar wood chips," Bioresource Technology 216, 317-322. DOI: 10.1016/j.biortech.2016.05.096

Yeniocak, M., Goktas, O., Erdil, Y. Z., Ozen, E., and Alma, M. H. (2014). "Investigating the use of vine pruning stalks (Vitis vinifera L. cv. 'Sultani') as raw material for particleboard manufacturing," Wood Research 59(1), 167-176. DOI:

Youngquist, J. A., English, B. E., Scharmer, R. C., Chow, P., and Shook, S. R. (1994). Literature Review on use of Nonwood Plant Fibers for Building Materials and Panels, (General Technical Report FPL-GTR-80) U.S. Department of Agriculture, Forest Service, Forest Products Laboratory, Madison, WI, USA.

Zhang, L., and Hu, Y. (2014). "Novel lignocellulosic hybrid particleboard composites made from rice straws and coir fibers," Materials and Design 55, 19-26. DOI: 10.1016/j.matdes.2013.09.066

Article submitted: July 01, 2020; Peer review completed: August 8, 2020; Revised version received and accepted: August 21, 2020; Published: August 27, 2020.

DOI: 10.15376/biores.15.4.7780-7795 